\title{
SHORT-TERM ( 3 MONTHS) COMPARED TO LONG-TERM RESPONSE TO SOMATOSTATIN ANALOGUES IN ACROMEGALY
}

Monica Livia Gheorghiu 1, 2, Madalina Vintila², Mariana Purice ${ }^{1}$, Catalina Poiana ${ }^{1,2,{ }^{*}, \text { Mihai Coculescu1, 2, }}$ 'National Institute of Endocrinology "C.I. Parhon", " "Carol Davila” University of Medicine and Pharmacy, Bucharest,

INTRODUCTION. In acromegaly, the reported therapeutical efficacy of somatostatin analogs (SSA), i.e. normalization of GH and IGF-1, is 50 - $70 \%$ (44 - $34 \%$ in unselected patients). This specific treatment is financially supported by the Romanian National House of Health Insurance for patients with acromegaly.

AIM OF STUDY: to retrospectively evaluate whether random GH and IGF-I levels achieved after 3 months of SSA treatment are predictive for the efficacy of SSA (lanreotide, octreotide) after longer treatment with the same dose.

METHOD: A retrospective review of 71 patients with acromegaly admitted in the Department of Neuroendocrinology, "C.I. Parhon" Institute, Bucharest (2006 - 2012) and treated for at least 6 months with SSA according to the Protocol of the Romanian National House of Health Insurance for patients with acromegaly. In 40 of them data on random serum GH and IGF-1 were available at baseline, after 3 months and at the last evaluation on the same SSA dose. Two patients have been evaluated on 2 different doses of SSA. In the other 31 patients not included in this study, the dosage has been either increased after 3 months - in 21 patients, or evaluated after $>3$ months - in 10 patients).

MATERIALS: Serum GH (usually in Parhon Institute): IRMA assay - MAIA Clone (Radim, Italy) - sandwich method with monoclonal a.b. - Sensibility 0.2 ng/mI. Serum IGF-1 (various laboratories, commercial kits). Follow-up protocol: random serum GH (mean of 4 blood samples extracted at 4 hours interval) and IGF-1 were measured at baseline and after $3,(6), 12$ and $>12$ months after therapy initiation. Optimal response to SSA included random GH $\leq 2.5 \mathrm{ng} / \mathrm{mL}$ and normal ageadjusted IGF-1 level.

\section{RESULTS}

\begin{tabular}{|l|l|}
\hline \multicolumn{2}{|c|}{$\begin{array}{c}\text { PATIENTS CHARACTERISTICS } \\
(\mathrm{n}=40 \text { patients })\end{array}$} \\
\hline Sex (F: M) & $28: 12$ \\
\hline $\begin{array}{l}\text { Age at diagnosis, mean } \pm \\
\text { SD, (range) }\end{array}$ & $\begin{array}{l}42 \pm 11.6 \text { years } \\
(22-62 \text { years) }\end{array}$ \\
\hline Previous pituitary surgery & 35 (29 SS, 4 FS, 2 SS+FS) \\
\hline $\begin{array}{l}\text { Previous radiotherapy or } \\
\text { radiosurgery }\end{array}$ & $\begin{array}{l}26 \text { (10 HVR, 2 NVR, 12 GK, } \\
1 \text { HVR+GK, 1 HVR+NVR ) }\end{array}$ \\
\hline $\begin{array}{l}\text { Tumor size at treatment } \\
\text { initiation }\end{array}$ & 25 macro, 15 micro \\
\hline
\end{tabular}

\begin{tabular}{|l|l|}
\hline \multicolumn{2}{|c|}{ SOMATOSTATIN ANALOG TREATMENT CHARACTERISTICS } \\
$(\mathrm{n}=\mathbf{4 0}$ patients) \\
\hline Treatment type $/$ no patients & $30 \mathrm{mg} / 14$ days $=15$ \\
Somatuline PR ( $\mathrm{n}=\mathbf{2 2}$ patients) & $30 \mathrm{mg} / 10$ days $=4$ \\
& $30 \mathrm{mg} / 7$ days $=3$ \\
Sandostatin LAR ( $=18$ patients) & $20 \mathrm{mg} / 28$ days $=10$ \\
& $30 \mathrm{mg} / 28$ days $=10$ \\
\hline $\begin{array}{l}\text { Treatment duration (until last follow-up on the same } \\
\text { SSA dosage), mean } \pm \text { SD }\end{array}$ & $15 \pm 10$ months \\
(range $5-44$ months)
\end{tabular}

Short vs longer-term response to SSA
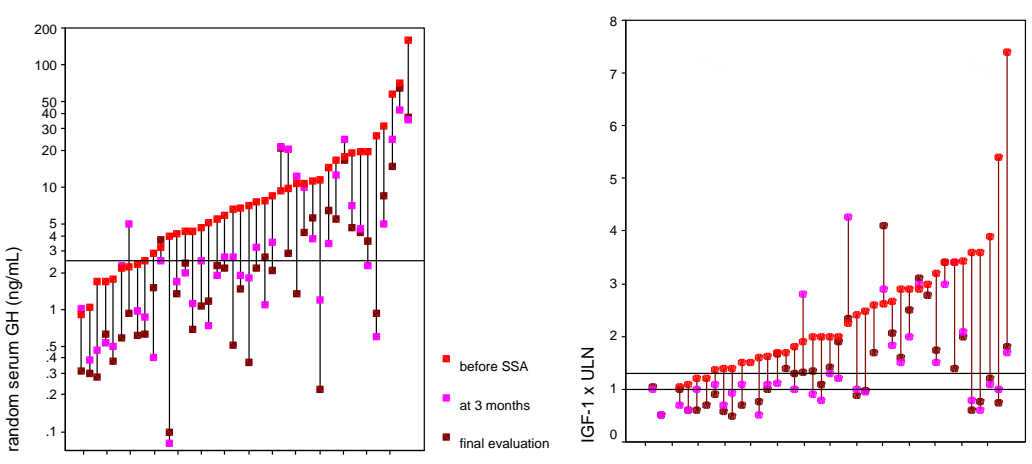

\begin{tabular}{|l|l|l|l|}
\hline & Before SSA & 3 months & last evaluation \\
\hline mean \pm SD random GH (ng/ml) & $14.9 \pm 27^{*}$ & $6.5 \pm 9.8$ & $5.7 \pm 0.6^{*}$ \\
\hline mean \pm SD IGF1 (x ULN) & $2.4 \pm 1.3^{*}$ & $1.5 \pm 0.9$ & $1.4 \pm 2.3^{*}$ \\
\hline
\end{tabular}

*P $<0.05$

GH normalization rate

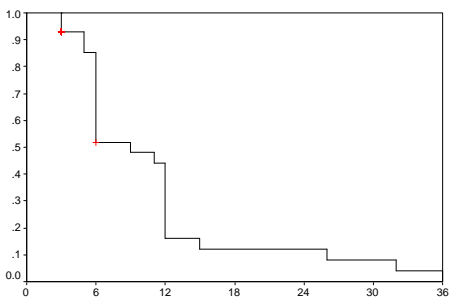

months

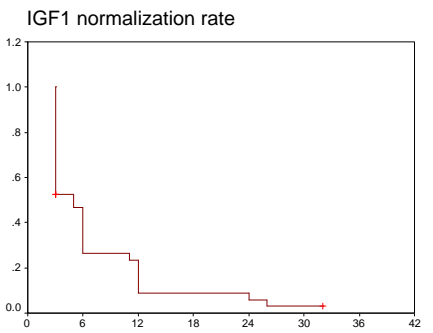

months

A random GH $\leq 2.5 \mathrm{ng} / \mathrm{mL}$ at 3 months has a $86.9 \%$ positive predictive value for normal $\mathrm{GH}$ at final evaluation and a $72.7 \%$ negative predictive value. Normal IGF-1 $(x$ ULN) $\leq 1$ at 3 months has a $85 \%$ positive predictive value for normal IGF-1 at final evaluation and a $83 \%$ negative predictive value.

Random GH response to SSA (3 months vs. final evaluation)

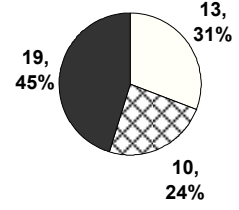

$\square</=1 \mathrm{ng} / \mathrm{ml} \square 1-2.5 \square>2.5$

Concordant values between the two points of evaluation were found in $33 / 42$ patients $(78.5 \%)$

\section{IGF-1 response to SSA}

Normal serum IGF-1 was recorded at 3 months in 20/35 patients $(57.1 \%)$ and at the last evaluation in $17 / 35$ patients $(48.5 \%)$, concordant values in $32 / 35$ patients $(91.4 \%)$.

Discordances between short and long-term response

Normal values at 3 months and elevated at the last evaluation were found:

- for $\mathrm{GH}$ in $3 / 42$ patients $(7.1 \%)$

- for IGF1 in $3 / 35$ patients $(8.5 \%, 2$ of them up to $1.3 \times$ ULN).

3 patients with IGF-1<1.3 x ULN at 3 months had higher final values.

Normalization only at the last evaluation was recorded in $6 / 42$ patients $(14 \%)$ only for $\mathrm{GH}$

Discordances GH - IGF1 (12/42 = 28.5\%)

Normal GH with high IGF-1 : 7 patients

High GH, normal IGF-1 : 5 patients

\section{CONCLUSION}

- In our series, the response to somatostatin analogues evaluated at 3 months was concordant with the response after longer treatment with the same dose in $78.5 \%$ of patients for $\mathrm{GH}$ and $91.4 \%$ for IGF-1.

-When discordances between IGF-1 and random GH occur at 3 months, we suggest a re-evaluation on the same SSA dose. If the discordance persists, a dosage increase should be considered. 